\title{
On the ecophysiology of the sponge Halichondria panicea in Kiel Bight. II. Biomass, production, energy budget and integration in environmental processes
}

\author{
Dagmar Barthel
}

Abteilung Meeresbotanik, Institut für Meereskunde, Düsternbrooker Weg 20, D-2300 Kiel 1, Federal Republic of Germany

\begin{abstract}
The role of the sponge Halichondria panicea was analyzed in the red algal zone of the Western Baltic. Data on biomass changes in a field population of $H$. panicea at Boknis Eck at the entrance of Eckernforde Bight agree well with observations from cage growth experiments (Barthel 1986); this indicates that the population suffers only negligible mortality through predators. Biomass data are combined with results on respiration rates (Barthel \& Theede 1986) to yield information on energy demand of this species. Using field data on water temperature and sediment structure in Kiel Bight estimates are made of total biomass and nutrient release by $H$. panicea in Kiel Bight. Field observations on the life cycle and relations to other animal species are discussed.
\end{abstract}

\section{INTRODUCTION}

The sponge Halichondria panicea Pallas occurs in sometimes enormous numbers in the red algal zone in the Western Baltic Sea. Despite its ubiquity, virtually nothing is known about its biomass, production and the role it plays in the red algal community.

The genera Phyllophora and Phycodrys form the preferred substrata for Halichondria panicea (Barthel 1986), implying that the majority of the sponges occur within the euphotic zone. Whereas studies have been made in this area on the role of some benthic infauna in energy and matter cycles (Graf et al. 1984) and on the importance of mobile epibenthos (Asmus et al. 1980), the role of sessile epibenthos such as sponges or tunicates has been more or less neglected up to now.

Considering the high biomass values these sponges can attain (Theede 1981), their population dynamics, energy demand and interactions with other community members certainly merit attention.

\section{MATERIALS AND METHODS}

Biomass data were collected at the 'Hausgarten' station at Boknis Eck near the entrance of Eckernförde Bight, Western Baltic Sea. Between December 1983 and April 1985 the sponge population was sampled by divers at about monthly intervals. A $0.25 \mathrm{~m}^{2}$ metal frame was deployed and all algal material within the frame was removed from the substratum and collected in net bags. Two parallel samples were taken at 6,8 and $10 \mathrm{~m}$ water depth at each sampling date. In the laboratory, general characteristics of the sample, e.g. mass occurrence or absence of single macrobenthos species, appearance and colour of sponges were recorded. The sponges were then removed from their substratum and the drained wet weight (WW) was determined. Subsamples were taken for the determination of dry weight (DW) and organic substance expressed as ash-free dry weight (AFDW). Biomass values are expressed as mean AFDW $\mathrm{m}^{-2}$.

Respiration rate measurements were carried out with a flow-through respirometer as described by Dries et al. (1978) and were published in an earlier paper (Barthel \& Theede 1986).

Temperature data for the sampled station were supplied by M. Weigelt \& P. Seifert and were published by Barthel (1986).

\section{RESULTS}

\section{Biomass and production}

Biomass of Halichondria panicea at Boknis Eck varied considerably with season at all 3 depths investi- 
gated (Fig. 1). Starting from a low biomass in winter, sponges began to grow in early spring, when ambient water temperature rose. At first, growth was slow, but accelerated towards summer. In August, highest biomass values were reached simultaneously at all depths, but while the biomasses found at 8 and $10 \mathrm{~m}$ depth were quite similar (about $24 \mathrm{~g} \mathrm{AFDW} \mathrm{m}^{-2}$ ), a much higher biomass of $40 \mathrm{~g}$ AFDW m $\mathrm{m}^{-2}$ was found at $6 \mathrm{~m}$ water-depth. At $6 \mathrm{~m}$, the vivid green colour of many sponges indicated the presence of high numbers of algae in the sponge tissue.
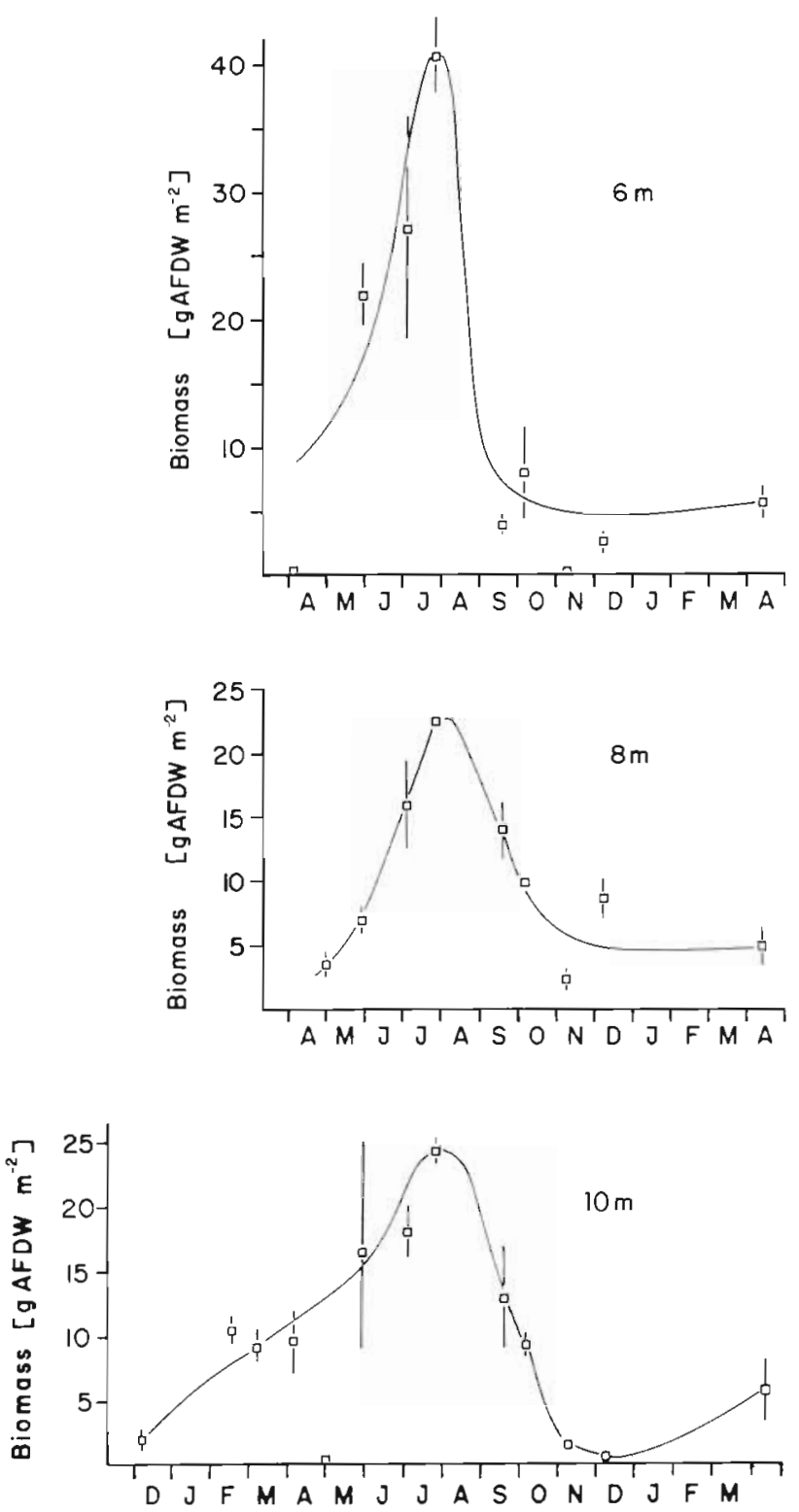

Fig. 1 Halichondria panicea. Development of biomass in the natural population at Boknis Eck, Western Baltic Sea at 6.8 and $10 \mathrm{~m}$ water depth. Curves are hand-fitted. Biomass development follows a similar time course at all depths with strong growth in early summer and decrease in fall. Note the high peak value in $6 \mathrm{~m}$ water-depth compared to 8 and $10 \mathrm{~m}$
After August, sponge biomass decreased at all depths; this process was accompanied by weight and size decrease of individual sponges and also by an alteration in sponge shape, which changed from lumpy/compact to a thin and stringy form. The same process has been recorded in cage experiments conducted at this station and was attributed mostly to degeneration of adult sponges after reproduction (Barthel 1986). During the time of most intense biomass loss in the field, the only ascertained predator of Halichondria panicea in the Western Baltic, the small dorid nudibranch Lamellidoris muricata O. F. Müller, occurred in very large numbers in the samples. Higher numbers were noted first in August and September and highest numbers of about 25 to 35 ind. $0.25 \mathrm{~m}^{-2}$ were recorded in October. In contrast, $L$. muricata was hardly detected at other times of the year.

From the data presented in Fig. 1, it is possible to calculate the minimum production of Halichondria panicea at the Boknis Eck station as the difference between the lowest and highest observed biomass (Arntz 1971): At 10 and $8 \mathrm{~m}$ depth, the lowest biomass value (December) was about $2 \mathrm{~g} \mathrm{AFDW} \mathrm{m}^{-2}$, at $6 \mathrm{~m}_{1}$ the lowest value (April) was about $8 \mathrm{~g} A F D W \mathrm{~m}^{-2}$; the highest (August) was $24 \mathrm{~g} \mathrm{AFDW} \mathrm{m}^{-2}$ at 8 and $10 \mathrm{~m}$ and $40 \mathrm{~g} \mathrm{AFDW} \mathrm{m}^{-2}$ at $6 \mathrm{~m}$ water-depth. Thus, minimum production amounts to $22(8$ and $10 \mathrm{~m})$ and $32 \mathrm{~g}$ AFDW $\mathrm{m}^{-2}(6 \mathrm{~m})$. The mean biomass would be 10.5 ( 8 and $10 \mathrm{~m})$ and $21 \mathrm{~g}$ AFDW $\mathrm{m}^{-2}(6 \mathrm{~m})$. This would mean rather low $\mathrm{P} / \mathrm{B}$ ratios of 2.1 ( 8 and $10 \mathrm{~m}$ ) and $1.8(6 \mathrm{~m})$, but it has to be borne in mind that this minimum production is certainly an underestimate as it neglects that part of production lost to predation etc. (Arntz 1971).

\section{Energy demand}

In combination with previous laboratory respiration experiments (Barthel \& Theede 1986) it is possible to calculate a minimum energy demand $C$ for this species ( $C=G+R+U+F$, where $C=$ consumption, $G=$ growth and reproduction, $U=$ excretion, $F=$ faeces, according to the formulation suggested by the International Biological Program (Crisp 1971\}). An example for $10 \mathrm{~m}$ water depth was obtained by performing the following steps: (1) Temperature data for the Boknis Eck station at different times during the year were taken and the respiration rate of Halichondria panicea at these temperatures was calculated or extrapolated from previous respiration measurements (Barthel \& Theede 1986, Fig, 2). (2) Respiration rates (ml O $\mathrm{O}_{2}$ [g AFDW $]^{-1} \mathrm{~h}^{-1}$ ) were multiplied by sponge biomass (data from Fig. 1, $10 \mathrm{~m}$ depth). Multiplied in turn by 24 , this yielded the respiration in $\mathrm{ml} \mathrm{O}_{2} \mathrm{~m}^{-2} \mathrm{~d}^{-1}$, neglecting possible circadian rhythms which might occur in the 
field. In the laboratory experiments, no such rhythms were observed during $24 \mathrm{~h}$ measurements. (3) By using the relation $1 \mathrm{ml} \mathrm{O} 2$ consumption $\triangleq 19.62 \mathrm{~J}$, the respiration data were converted into energy demand. (4) Energy loss via respiration was assumed to account for $50 \%$ of the total food energy requirement $C$, which in turn was calculated by multiplying the Joule values by a factor 2 .

Table 1 gives a summary of the calculations done and the data used as a basis. Results in terms of energy requirements of Halichondria panicea over the year are illustrated in Fig. 3. The combined effects of high biomass values in summer and higher temperatures requiring more energy for total energy expenditure cause a pronounced peak of estimated energy demand in August. After August, quickly decreasing biomass values, even more than lower temperatures, cause food energy demand to fall again.

The main questions arising from these calculations are: (1) How is the estimated energy demand met during various times of the year? (2) How high a biomass does Halichondria panicea constitute in Kiel

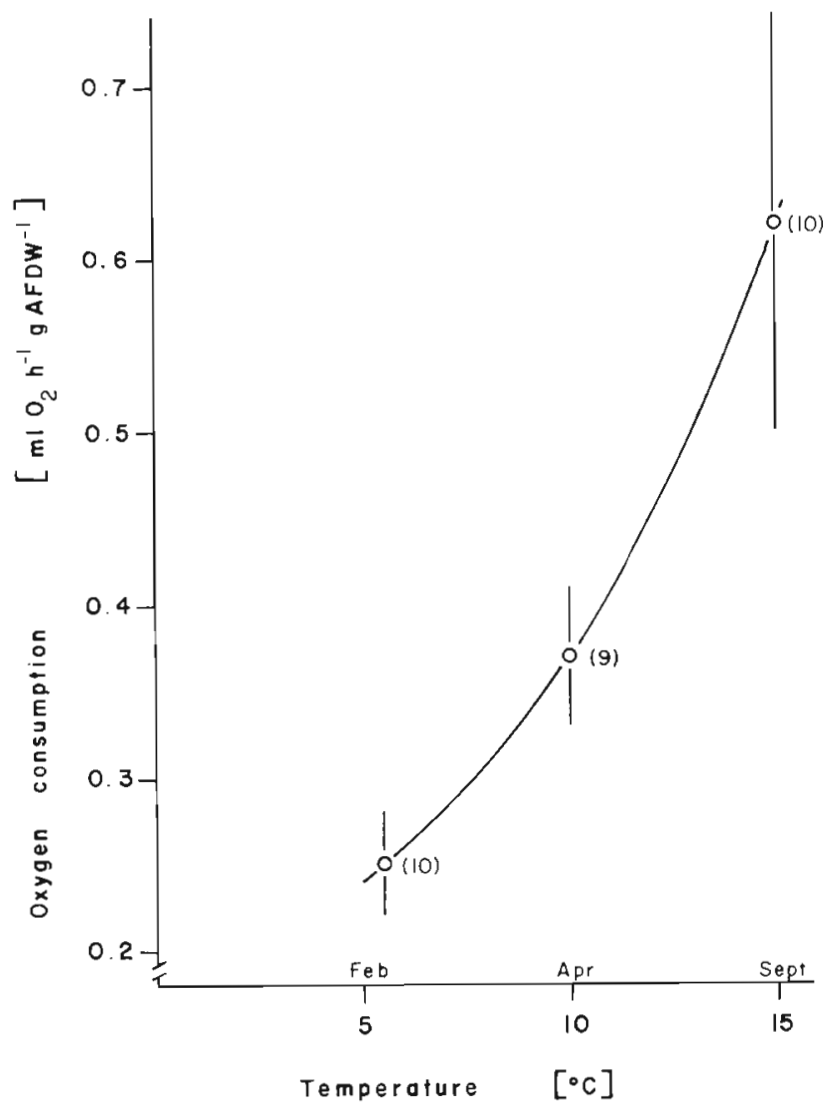

Fig. 2. Halichondria panicea. Dependence of oxygen consumption on temperature. Acclimation time in the lab at least $3 \mathrm{wk}$. Duration of each measurement about $24 \mathrm{~h}$. Values in brackets: number of parallel experiments. From Barthel \& Theede (1986)
Bight and (3) How is this biomass built up by sponges in spring and early summer utilized in the Kiel Bight food web?

\section{DISCUSSION}

The results on biomass development of Halichondria panicea at Boknis Eck in the Western Baltic Sea are in excellent agreement with those drawn from cage growth experiments at the same location (Barthel 1986; Fig. 4). In spring, growth seems to be primarily dependent on ambient water temperature and even a good supply of food during spring phytoplankton bloom in March when water temperatures are low does not trigger growth. Comparison with cage growth experiments shows that growth of $H$. panicea in the field really lasts until the middle of August, which could not be documented with the cages due to sampling difficulties (Barthel 1986). Furthermore, as mean individual size investigated with the cages and population biomass observed in the field show exactly the same qualitative and quantitative development (cages: increase from 100 to $240 \%$ mean individual organic body mass between March and August; field biomass: increase from 10 to about $24 \mathrm{~g} \mathrm{AFDW} \mathrm{m}^{-2}$ during the same time span), it can be argued that loss of whole sponges, e.g. by predation or mortality, is negligible in this biotope. If destruction of whole sponges was occurring, biomass reached in the field would - on the basis of identical growth rates in cages and in the field - be visibly lower. This conclusion confirms the view of Burton (1948), who argued that death of whole $H$. panicea occurred comparatively seldom, but that older sponge parts disappeared with time.

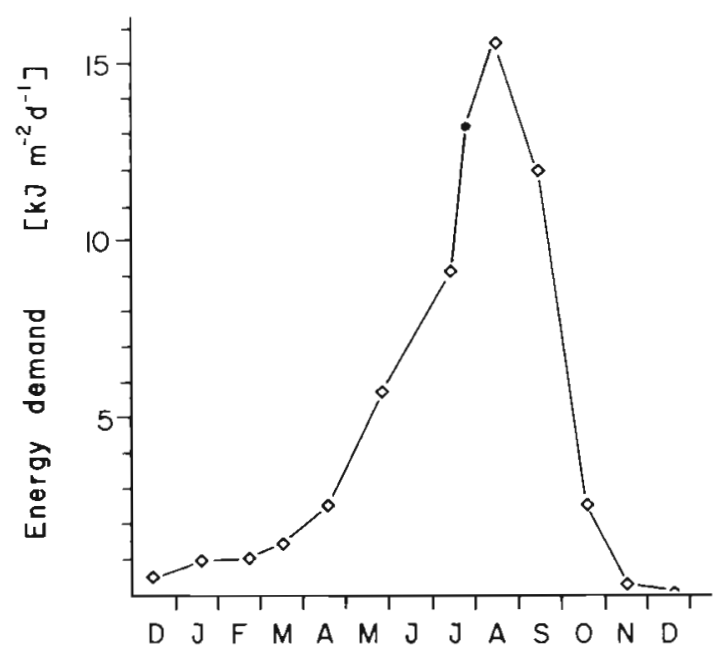

Fig. 3. Halichondria panicea. Food energy demand at the Boknis Eck station, $10 \mathrm{~m}$ water-depth, 1984. Data from Table 1 


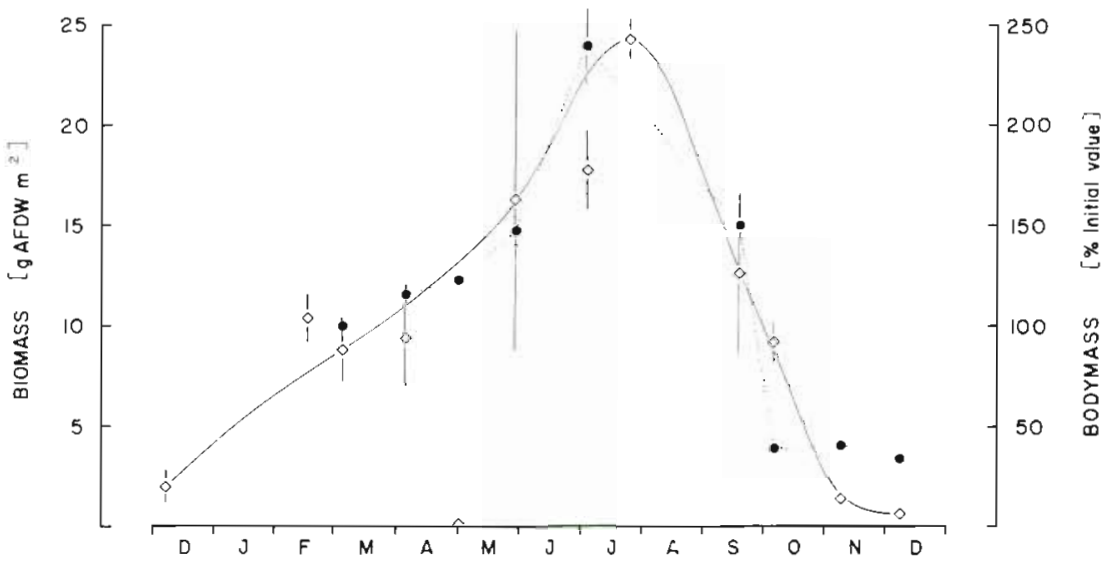

Fig. 4. Halichondria panicea. Comparison of results from field growth experiments $(\cdots \cdots \cdot)$ and monitoring of biomass development ( - ) atr the Boknis Eck station, $10 \mathrm{~m}$ water-depth. Means and standard deviation of means. Curves are almost parallel and respective units show that the development matches qualitatively as well as quantitatively

In other marine areas predation on sponges can be quite important and often serves to control population development (Bakus 1964, 1969, Carefoot 1967, Randall \& Hartman 1968, Elvin 1976, Guida 1976, Dayton 1979). The relative absence of predators in Kiel Bight is probably partly caused by low salinities (10 to $25 \%$ ) inhibiting the invasion of osmotically less resistant species. Up to now we lack data concerning the grazing potential of the common sponge-eating dorid nudibranch Lamellidoris muricata, so it is very difficult to assess its impact on the sponge population.

Low salinities and ensuing osmotic stress may also be a reason for the rather low $\mathrm{P} / \mathrm{B}$ ratio found for Halichondria panicea. Observations (Barthel 1986) indicate that the life of a $H$. panicea starts with release of larvae about August and ends with the sponge's degeneration after reproduction the following year about December, when the sponges usually almost totally disappear.
This implies a mean life span of about $1.5 \mathrm{yr}$ in the Baltic Sea red algal zone (life spans are higher in the North Sea; Barthel 1985). According to an equation by Robertson (1979) the P/B ratio for a species with this life span should be 3.55 , not 2.1 at 8 and $10 \mathrm{~m}$ and 1.8 at $6 \mathrm{~m}$ respectively, found for $H$. panicea. Waters (1977) gives a $\mathrm{P} / \mathrm{B}$ ratio of 5 for univoltine species, and of 2 for hemivoltine species. If we assume the life span of $H$. panicea to range somewhere between these extremes a mean $\mathrm{P} / \mathrm{B}$ ratio of 3.5 would result. On the other hand, it is also possible that $P / B$ ratios calculated for metazoans do not hold for the more simply organized sponges. As data of sponge $\mathrm{P} / \mathrm{B}$ ratios are lacking, and my calculations are based on minimum production, this hypothesis requires further investigation.

Biomass measurements of Halichondria panicea have never been performed in a larger area of Kiel Bight; the only other data available also derives from

Table 1. Halichondria panicea. Calculation of energy demand at the Boknis Eck station in $10 \mathrm{~m}$ water depth, 1984. Dates are those of the temperature measurements, except ', which is the date of highest sponge biomass in the field; respiration rate at this temperature calculated from laboratory experiments (Barthel \& Theede 1986); biomass calculated from biomass curve (Fig. 1) oxygen consumption calculated by multiplying respiration rate $\times$ biomass $\times 24$ h; energy requirement for respiration alone based on the conversion factor $1 \mathrm{ml}$ oxygen consumption $\hat{=} 19.62 \mathrm{~kJ}$; total food energy demand $C$ based on the assumption that respiration accounts for $50 \%$ of total energy consumption

\begin{tabular}{|c|c|c|c|c|c|c|}
\hline Date & $\begin{array}{c}\text { Water } \\
\text { temperature } \\
\left({ }^{\circ} \mathrm{C}\right)\end{array}$ & $\begin{array}{c}\text { Respiration } \\
\text { rate } \\
\mathrm{mlO}_{\angle} \mathrm{gAFDW}^{-1} \mathrm{~h}^{-1}\end{array}$ & $\begin{array}{c}\text { Biomass } \\
\text { (g AFDW m }{ }^{-2} \text { ) }\end{array}$ & $\begin{array}{c}\text { Oxygen } \\
\text { consumption } \\
\left(\mathrm{mlO}_{2} \mathrm{~m}^{-2} \mathrm{~d}^{-1}\right)\end{array}$ & $\begin{array}{l}\text { Energy require- } \\
\text { ment of resp. } \\
\left(\mathrm{kJ} \mathrm{m} \mathrm{m}^{-2} \mathrm{~d}^{-1}\right)\end{array}$ & $\begin{array}{c}\text { Total energy } \\
\text { demand } \\
\left(\mathrm{kJ} \mathrm{m}^{-2} \mathrm{~d}^{-1}\right)\end{array}$ \\
\hline $14 \operatorname{Dec} 83$ & 4.6 & 0.21 & 2.5 & 12.6 & 0.25 & 0.50 \\
\hline $18 \operatorname{Jan} 84$ & 3.0 & 0.18 & 6.0 & 25.2 & 0.50 & 1.00 \\
\hline 22 Feb 84 & 1.4 & 0.15 & 7.5 & 26.1 & 0.51 & 1.02 \\
\hline 16 Mar 84 & 1.9 & 0.16 & 9.5 & 36.5 & 0.72 & 1.44 \\
\hline 17 Apr 84 & 4.7 & 0.22 & 12.0 & 63.4 & 1.24 & 2.48 \\
\hline 25 May 84 & 10.7 & 0.40 & 15.0 & 144.0 & 2.83 & 5.66 \\
\hline 13 Jul 84 & 13.4 & 0.55 & 17.5 & 231.0 & 4.53 & 9.06 \\
\hline $25 \mathrm{Jul} 84^{\circ}$ & 14.0 & 0.58 & 24.0 & 331.0 & 6.50 & 13.00 \\
\hline 15 Aug 84 & 16.1 & 0.70 & 23.5 & 394.8 & 7.75 & 15.50 \\
\hline 14 Sep 84 & 14.7 & 0.61 & 14.0 & 203.3 & 3.99 & 7.98 \\
\hline $180 \mathrm{Ot} 84$ & 12.6 & 0.49 & 5.5 & 64.0 & 1.26 & 2.52 \\
\hline 15 Nov 84 & 9.5 & 0.35 & 1.0 & 8.3 & 0.16 & 0.32 \\
\hline $18 \operatorname{Dec} 84$ & 4.6 & 0.21 & 0.5 & 2.5 & 0.05 & 0.10 \\
\hline
\end{tabular}


Boknis Eck station (Theede 1981). Hence, in calculating a total for the Bight, we must rely on data from this site alone. However, since previous workers have assumed the ecological situation at Boknis Eck to be fairly typical for the Western Baltic Sea (e.g. Martens 1975), we may assume the sponge biomass found in the red algal zone between 2 and $10 \mathrm{~m}$ at Boknis Eck to be typical for the area considered.

Macroalgae, which form the most important substrate for Halichondria, need substrata like bedrock or glacial lag sediment (stones up to boulder size). While bedrock is not exposed in Kiel Bight, Babenerd \& Gerlach (1987), report that $530 \mathrm{~km}^{2}$ or $21 \%$ of Kiel Bight is covered with lag sediment. With few exceptions (Black 1978), H. panicea only occurs from 2 to about $10 \mathrm{~m}$ water depth in the Baltic, leaving $203 \mathrm{~km}^{2}$ or $8 \%$ as an area suitable for the settlement of macroalgae forming the most important substrate for Halichondria. Thus the total sponge biomass in Kiel Bight in 1984 amounts to between $400 \mathrm{t}$ AFDW in winter and $4900 \mathrm{t}$ in summer.

Biomass development in Halichondria panicea through the year closely resembles that of other macrobenthos (e.g. Anders \& Möller 1984, Brey 1984). But different species of macrofauna with similar seasonal development can have quite different impacts on the ecosystem, depending on their location and metabolic strategy. Many quantitatively important benthic invertebrates in the Baltic Sea store energy during sedimentation of the spring phytoplankton bloom and later utilize e.g. stored glycogen to meet their energy requirements for growth, metabolism and reproduction (Graf et al. 1984). H. panicea does not store large amounts of glycogen or fat during the spring bloom (Barthel 1986), nor have high amounts of glycogen been found in other sponge species (Stone 1970, Elvin 1979). This and the fact that low ambient temperatures prevent $H$. panicea from taking advantage of the high food concentrations during the spring phytoplankton bloom imply that the sponge probably has to rely mostly on phytoplankton production in summer, as does herbivorous zooplankton. The role of dissolved organic matter, known to be important for other species (e.g. Reiswig 1974, Ferguson 1982) cannot be assessed as yet for $H$. panicea. According to Reiswig (1974), dissolved organic matter is probably not taken up by the sponge cells themselves in the first place, but by symbiotic bacteria (for a detailed discussion of this problem see Vacelet 1979). Electron microscope studies have not revealed such symbiotic bacteria in $H$. panicea (Barthel 1985, Langenbruch pers. comm.). Hence, $H$. panicea seems to occupy a similar nutritional niche to herbivorous zooplankton and is less comparable to those macrobenthos species possessing energy stores, such as bivalves.
In the calculations leading to Table 1 and Fig. 3 , suspended particulate matter is thus considered to be the prime energy source sustaining the observed growth. Energy loss via respiration is assumed to account for $50 \%$ of the total food energy requirement $\mathrm{C}=\mathrm{G}+\mathrm{R}+\mathrm{U}+\mathrm{F}$. This estimate is mainly derived from results obtained by Reiswig $(1971,1974)$ on Mycale sp. The resulting food energy demand (Fig. 3) of Halichondria panicea peaks during summer, and a corresponding part of the shallow water phytoplankton, detritus and bacteria, which also serve as food, is removed from the water column by the sponges.

This means that the food energy taken up by this organism is quite considerable and the corresponding excretion of plant nutrients coupled to this energy flux should be intense. We have as yet no direct measurements of sponge phosphorus and nitrogen excretion, but on the basis of the respiration measurements and the Redfield ratio of $\mathrm{C}: \mathrm{N}: \mathrm{P}$ of $106: 16: 1$ (Redfield 1934 in Parsons et al. 1984) we can calculate that during the time of highest oxygen consumption (Fig. 3) H. panicea takes up about $0.36 \mathrm{~g} \mathrm{C} \mathrm{m}^{-2} \mathrm{~d}^{-1}$, of which $50 \%$ are lost by respiration. According to the Redfield ratio this would correspond to $0.023 \mathrm{~g} \mathrm{~m}^{-2} \mathrm{~d}^{-1}$ excreted inorganic nitrogen and $0.0007 \mathrm{~g} \mathrm{~m}^{-2} \mathrm{~d}^{-1}$ excreted phosphate-phosphorus or 4.7 tons inorganic nitrogen and 0.4 tons phosphate-phosphorus per day in Kiel Bight. These amounts are much lower than those calculated for example for Mytilus edulis in the Eastern Baltic by Kautsky \& Wallentinus (1980), but a much greater amount of nutrients will be released during the time of degeneration of the adults within the euphotic zone. If we assume that practically all sponge biomass produced during spring and summer is remineralized, and again apply the Redfield ratio, this yields a release of about $2350 \mathrm{t}$ carbon, $303 \mathrm{t}$ nitrogen and $9 \mathrm{t}$ phosphate in the second half of the year which certainly contributes to the sustenance of the summer and fall phytoplankton production.

The calculations presented so far bear uncertainties in the respiration rates: firstly respiration rates vary individually to a large extent, and secondly it is problematic to use uncorrected field AFDWs as a biomass basis for these calculations in an organism where a large part of the organic substance is metabolically inactive skeletal protein, and moreover recent investigations (Barthel unpubl.) have shown that the amount of skeletal material and thus activity of Halichondria panicea varies with season. Also the presence of varying numbers of probably photosynthetically active algae in the sponge tissue might affect respiration and nutrient release and perhaps growth of $H$. panicea (for a discussion of sponge/algae symbioses see Sará \& Liaci 1964a, b, Sará 1966, 1971, Eimhjellen 1967, Muscatine et al. 1967, Gilbert \& Allen 1973, Wilkinson \& 
Vacelet 1979, Frost \& Williamson 1980, Christensen 1985).

Halichondria probably also influences sedimentation. Of the materials Halichondria filters through its aquiferous system, a certain part will leave again as either feces or pseudofeces, i.e. material taken up and exocytosed by the sponge undigested as larger membrane-covered units. These particles will sink to the bottom more quickly than the original small particles ingested. So while the absolute amount of sedimentable material in summer is reduced by the activity of the sponge, the part passing through it will sink more quickly, resulting in an even flow of food to the bottom community in the sedimentation-poor period of summer.

The question of the fate of the sponge biomass, i.e. how much will enter the sedimentation process and detrital food chain, how much will be reconverted into dissolved plant nutrients and dissolved organic matter, and how much will be either washed ashore or transported as bed load into the deeper muddy parts of Kiel Bight remains to be investigated.

Besides influencing primary production and sedimentation, Halichondria panicea also has a structuring effect by being obligatory or additional host for a number of other organisms in the Kiel Bight area. The hydrozoan Dipurena spongicola spends its entire life cycle in $H$. panicea (Anger 1972) and the polychaete Polydora ciliata which normally bores in clam shells and similar substrata settles on the sponge surface (Hempel 1957, author's obs.) as do a number of ciliates, nematodes and ostracods (Anger 1972). Hence, $H$. panicea contributes to the diversity in the red algal community.

\section{CONCLUSIONS}

In terms of both biomass and energetics, the sponge Halichondria panicea comprises an interesting compartment of the Kiel Bight ecosystem. Its most notable interaction with the ecosystem is withdrawal of shallow-water phytoplankters from the euphotic zone in summer, when the sponge's energy demand is greatest, and in turn supplying plant nutrients and dissolved organic substance to the system. In the absence of noteworthy predation, only a minor share of sponge biomass in the Western Baltic Sea seems to be transported directly to higher trophic levels. Most seems to be recycled immediately within the euphotic zone, or to enter the detrital food chain. Hence, sponges can be considered as a trophic loop, converting phytoplankton into animal biomass in the euphotic zone, thus diminishing the amount of sedimenting organic substance in summer; on the other hand, sponges also enhance sedimentation speed for particles passing through them undigested. This again influences the flux of energy and matter from water to sediment. Year-toyear variations in total sponge biomass are likely to divert the flow of primary production either more to the detritus food chain, or, when sponge biomass is low, more to the grazing food chain.

Nutrient excretion by sponges stabilizes primary production in summer; in late summer, when nutrients in the water column are depleted, degeneration and disintegration of sponges again provide a nutrient pulse to primary producers. Nutrients appear never to be really depleted in the immediate vicinity of sponge- and other macrobenthos-bearing algae (Schramm pers. comm.), but to be continuously and quickly recycled along the short pathways between substrate algae and epibiont Thus, measurements of nutrient release by both metabolically active and degenerating sponges are desirable. Halichondria panicea also adds to the diversity of the red algal community, by supplying substrate for other macrobenthos. Sponges and other epibenthic animals, such as tunicates, deserve more attention in energy budgets calculated for the Kiel Bight area.

Acknowledgements. This study contains parts of the author's doctoral thesis which was generously supported by a fellowship from 'Studienstiftung des deutschen Volkes'. The skill of many members of the Kiel University Scientific Diving Group was indispensable in collecting the samples. For advice and valuable discussions thanks are due to $\mathrm{S}$. A. Gerlach, $\mathrm{H}$. Theede, F. Pollehne and R. Schmaljohann. I also acknowledge the helpful and constructive comments of the anonymous reviewers.

\section{LITERATURE CITED}

Anders, K., Möller, H. (1984). Seasonal fluctuations in macrobenthic fauna of the Fucus belt in Kiel Fjord (western Baltic Sea). Helgoländer Meeresunters. 36: 277-283

Anger, K. (1972). Dipurena spongicola sp. n. (Hydrozoa, Corynidae), ein in Schwämmen lebender Hydroidpolyp aus dem Kattegat und der nördlichen Kieler Bucht. Kieler Meeresforsch. 28: 80-83

Arntz, W. E. (1971). Biomasse und Produktion des Makrobenthos in den tieferen Teilen der Kieler Bucht im Jahr 1968 Kieler Meeresforsch. 27 (1): 36-72

Asmus, H., Theede, H., Neuhoff, H.-G., Schramm, W (1980). The role of epibenthic macrofauna in the oxygen budget of Zostera communities from the Baltic Sea. Ophelia (Suppl. 1): 99-111

Babenerd, B., Gerlach, S. A. (1987). Bathymetry and sediments of Kieler Bucht. In: Rumohr, J., Walger. E., Zeitzschel, B. (eds.) Seawater-sediment interactions in coastal waters. An interdisciplinary approach. Lecture Notes on Coastal and Estuarine Studies 13. Springer-Verlag, Berlin, p. 15-32

Bakus. G. J. (1964). The effects of fish-grazing on invertebrate evolution in shallow tropical waters. Allan Hancock Found. Publ. Occ. Pap. 27 1-29

Bakus. G. J. (1969). Energetics and feeding in shallow marine waters. Int. Rev. gen. exp. Zool. 4: 275-369 
Barthel, D. (1985). Experimentelle Untersuchungen zur Okologie von Halichondria panicea (Porifera) aus der Nord- und Ostsee. Ph.D. thesis, Christian-Albrechts-University, Kiel

Barthel. D. (1986). On the ecophysiology of the sponge Halichondria panicea in Kiel Bight. I. Substrate specificity, growth and reproduction. Mar Ecol. Prog. Ser 32: 291-298

Barthel, D., Theede, H. (1986). A new method for the culture of sponges and its application to experimental studies. Ophelia 25 (2): $75-82$

Black, H. J. (1978). The colonization of artificial hard substrates by benthic macro-algae in Kiel Bay - a pilot study. Kieler Meeresforsch. (Suppl. 4): 98-101

Brey, T (1984). Gemeinschaftsstrukturen, Abundanz, Biomasse und Produktion des Makrozoobenthos sandiger Böden der Kieler Bucht in 5-15 m Wassertiefe. Ber. Inst. Meeresk. Univ, Kiel 123: 1-124

Burton, M. (1948). Observations on sponges, including the supposed swarming of larvae, movement and coalescence in mature individuals, longevity and death. Proc. zool. Soc. Lond. 118: 893-915

Carefoot, T. (1967). Growth and nutrition of three species of opistobranch molluscs. Comp. Biochem. Physiol. 21: $627-652$

Christensen, T. (1985). Microspora ficulinae, a green alga living in marine sponges. Br Phycol. J. 20 (1): 5-7

Crisp, D. J. (1971). Energy flow measurements. In: Holme, N. A., McIntyre, A. D. (eds.) Methods for the study of marine benthos. IBP Handbook No, 16. Blackwell, Oxford, p. $197-279$

Dayton, P. K. (1979). Observations on growth, dispersal and population dynamics of some sponges in McMurdo Sound, Antarctica. In: Lévi, C., Boury-Esnault, N. (eds.) Biologie des Spongiaires. Colloqu. Internat. C.N.R.S., Paris 291. $271-282$

Dries, R.-R., Eschweiler, L., Theede, H. (1978). An improved equipment for continuous measurement of respiration of marine invertebrates. Kieler Meeresforsch. (Suppl. 4): 310-316

Eimhjellen, K. E. (1967). Photosynthetic bacteria and carotenoids from a sea sponge Halichondrium panicea. Acta Chem. Scand. 21: 2280-2281

Elvin, D. W (1976). Feeding of a dorid nudibranch, Diaulula sandiegensis on the sponge Haliclona permollis. Veliger 19 (2): $194-198$

Elvin, D. W. (1979). The relationship of seasonal changes in the biochemical components to the reproductive behaviour of the intertidal sponge Haliclona permollis. Biol. Bull. mar. biol. Lab., Woods Hole 156: 47-61

Ferguson, J. C. (1982). A comparative study of the net benefits derived from the uptake and release of free amino acids by marine invertebrates. Biol. Bull. mar, biol. Lab., Woods Hole 162: 1-17

Frost, M. F., Williamson, E. (1980). In situ determination of the effect of symbiotic algae on the growth of the freshwatersponge Spongilla lacustris. Ecology 61: 1361-1370

Gilbert, J. J., Allen, H. L. (1973). Studies on the physiology of the green freshwater sponge Spongilla lacustris: primary productivity, organic matter, and chlorophyll content. Verh. int. Verein. Limnol. 18: 1413-1420

Graf, G., Bengtsson, W., Faubel, A., Meyer-Reil, L.-A., Schulz,
R., Theede, H. Thiel H. (1984). The importance of the spring phytoplankton bloom for the benthic system of Kiel Bight. Rapp. P.-v. Réun. Cons. int. Explor. Mer 183: 99-111

Guida, V G. (1976). Sponge predation in the oyster reef community as demonstrated with Cliona celata Grant. J. exp. mar. Biol. Ecol. 25: 109-112

Hempel, C. (1957). Zur Ökologie einiger Spioniden (Polychaeta sedentaria) der deutschen Küsten. Kieler Meeresforsch. 13: $275-288$

Kautzky, N., Wallentinus, I. (1980). Nutrient release from a baltic Mytilus-red algae community and its role in benthic and pelagic productivity. Ophelia (Suppl. 1): 17-30

Martens, P. (1975). Über die Qualität und Quantität der Sekundär- und Tertiärproduzenten in einem marinen Flachwasserökosystem der westlichen Ostsee. Doctoral thesis, Christian-Albrechts-University, Kiel

Muscatine, L., Karakashian, S. J., Karakashian, M. W. (1967). Soluble extracellular products of algae symbiotic with a ciliate, a sponge and a hydra. Comp. Biochem. Physiol. 20: $1-12$

Parsons, T. R., Takahashi, M., Hargrave, B. (1984). Biological oceanographic processes, 3rd edn. Pergamon Press, New York

Randall, J. E., Hartman, W. D. (1968). Sponge-feeding fishes of the West Indies. Mar. Biol. 1. 216-225

Reiswig, H. M. (1971). Particle feeding in natural populations of three marine demosponges. Biol. Bull. mar. biol. Lab., Woods Hole 141. 568-591

Reiswig, H. M. (1974). Water transport, respiration and energetics of three tropical marine sponges. J. exp. mar. Biol. Ecol. 14: 231-249

Robertson, A. I. (1979). The relationship between annual production : biomass ratios and lifespans for marine macrobenthos. Oecologia 38: 193-202

Sará, M. (1966). Associazioni fra Poriferi e alghe in acque superficiali del litorale marino. Ricerca scient. 36: 277-282

Sará, M. (1971). Ultrastructural aspects of the symbiosis between two species of the genus Aphanocapsa (Cyanophyceae) and Ircinia variabilis (Demospongiae). Mar. Biol. 11: 214-221

Sará, M., Liaci, L. (1964a). Associazioni fra la Cianoficea Aphanocapsa feldmanni e alcune Demospongie marine. Boll. Zool. 31: 55-65

Sará, M., Liaci, L. (1964b). Symbiotic associations between zooxanthellae and two marine sponges of the genus Cliona. Nature, Lond. 203: 321

Stone, A. R. (1970). Seasonal variation in the gross biochemical composition of Hymeniacidon perleve (Montagu). J. exp. mar. Biol. Ecol. 5: 265-271

Theede, H. (1981). Studies on the role of benthic animals of the Western Baltic in the flow of energy and organic material. Kieler Meeresforsch. (Suppl. 5) : 434-444

Vacelet, J. (1979). La place des spongiaires dans les systemes trophiques marins. In: Lévi, C., Boury-Esnault, N. (eds.) Biologie des Spongiaires. Colloq. Internat. C.N.R.S., Paris 291: 259-270

Waters, T. F. (1977). Secondary production in inland waters. Adv. Ecol. Res. 10: 91-164

Wilkinson, C. R., Vacelet, J. (1979). Transplantation of marine sponges to different conditions of light and current. J. exp. mar. Biol. Ecol. 37: 91-104 